\title{
Managing cattle grazing intensity: effects on soil organic matter and soil nitrogen
}

\author{
Moran Segoli ${ }^{\mathrm{A}, \mathrm{G}}$, Steven Bray ${ }^{\mathrm{B}}$, Diane Allen ${ }^{\mathrm{C}}$, Ram Dalal ${ }^{\mathrm{C}}$, Ian Watson ${ }^{\mathrm{D}}$, Andrew Ash ${ }^{\mathrm{E}}$, \\ and Peter O'Reagain ${ }^{\mathrm{F}}$ \\ ${ }^{\mathrm{A} C S I R O}$ Land and Water, PMB Aitkenvale, Qld 4814, Australia. \\ ${ }^{B}$ Dept of Agriculture and Fisheries (DAF), PO Box 6014, Redhill Rockhampton, Qld 4702, Australia. \\ CLandscape Sciences (ESP), Dept of Science, Information Technology and Innovation (DSITIA), \\ GPO Box 2454, Brisbane, Qld 4001, Australia. \\ ${ }^{\mathrm{D} C S I R O}$ Agriculture, PMB Aitkenvale, Qld 4814, Australia. \\ ${ }^{\mathrm{E} C S I R O}$ Agriculture, Dutton Park, Qld 4102, Australia. \\ FDAF, PO Box 976, Charters Towers, Qld 4820, Australia. \\ ${ }^{\mathrm{G} C}$ Corresponding author. Email: moran.segoli@gmail.com
}

\begin{abstract}
Extensive cattle grazing is the dominant land use in northern Australia. It has been suggested that grazing intensity and rainfall have profound effects on the dynamics of soil nutrients in northern Australia's semi-arid rangelands. Previous studies have found positive, neutral and negative effects of grazing pressure on soil nutrients. These inconsistencies could be due to short-term experiments that do not capture the slow dynamics of some soil nutrients and the effects of interannual variability in rainfall. In a long-term cattle grazing trial in northern Australia on Brown Sodosol-Yellow Kandosol complex, we analysed soil organic matter and mineral nitrogen in surface soils $(0-10 \mathrm{~cm}$ depth) 11, 12 and 16 years after trial establishment on experimental plots representing moderate stocking (stocked at the longterm carrying capacity for the region) and heavy stocking (stocked at twice the long-term carrying capacity). Higher soil organic matter was found under heavy stocking, although grazing treatment had little effect on mineral and total soil nitrogen. Interannual variability had a large effect on soil mineral nitrogen, but not on soil organic matter, suggesting that soil nitrogen levels observed in this soil complex may be affected by other indirect pathways, such as climate. The effect of interannual variability in rainfall and the effects of other soil types need to be explored further.
\end{abstract}

Received 27 August 2014, accepted 12 May 2015, published online 11 September 2015

\section{Introduction}

Many of northern Australia's soils are low in nutrients. This is because Australian landscapes are weathered relics of earlier pedological processes (Mott et al. 1985). In addition, northern Australia has a short and unreliable growing season and a long dry season, making it difficult for cropping to be practiced (Carberry et al. 1993). As a result, commercial cattle grazing is by far the dominant land use, by area, over much of northern Australia, occupying 2.5 million $\mathrm{km}^{2}$ of tropical semi-arid savannas and grasslands (Cook et al. 2010). Because of this large area, grazing management practices that cause changes in soil nutrient dynamics could potentially affect national- or even global-scale processes. For example, it has been suggested that by improving land management, and hence land condition, in the livestock-grazed landscapes of northern Australia, hundreds of millions of tonnes of carbon could be sequestered in the top $10 \mathrm{~cm}$ of the soil (Ash et al. 1995; Garnaut 2008; Eady et al. 2009; Gifford 2010). In addition to helping reduce atmospheric $\mathrm{CO}_{2}$ concentrations, this has the potential to improve soil and pasture productivity, improve livestock productivity and increase graziers' income through a higher value of livestock sales and incentives for carbon storage. This is especially important because grazing enterprises in north Australia are only marginally profitable (McLean et al. 2014). Finally, improving pasture and land condition can increase rainfall infiltration and decrease erosion, which is a major threat to the water quality of the Great Barrier Reef Lagoon (O'Reagain et al. 2005).

The soils of northern Australia are highly heterogeneous because of factors such as underlying geology, position in the landscape, climate and land use (Mott et al. 1985). Variations in soil properties may have a strong effect on pasture growth. For example, Mott et al. (1985) suggested that nitrogen was limiting for pasture growth on sesquioxidic soils, whereas soil water availability was limiting on the more fertile texture contrast soils. In other soils, water availability limited pasture growth in the drier years, whereas in wetter years pasture growth was limited by soil nitrogen (Mott et al. 1985). Furthermore, the effects of grazing depend on the soil type (McSherry and Ritchie 2013) and nutrient uptake by plants (Ash and McIvor 1995). For example, in northern Australia, higher grazing intensity was found to decrease soil carbon and nitrogen on Grey Vertosol and 
Red Kandosol but to increase soil carbon on a Brown SodosolYellow Kandosol complex (Pringle et al. 2011, 2014). Such variation suggests that the effects of grazing management on soil nutrient dynamics should consider local conditions and be extrapolated with caution.

Nitrogen and carbon dynamics are inextricably connected and cannot be understood independently of each other (Wedin 1995). The net amount of nitrogen mineralisation and availability to plants may be restricted by the high $\mathrm{C}: \mathrm{N}$ ratio of soil organic matter (Mott et al. 1985; Wedin 1995). In addition, it has been suggested that there is a negative relationship between average rainfall and available nitrogen (Liebig et al. 2014). Therefore, it is important to manage the ecosystem for adequate available nitrogen. Even when soil nitrogen cannot be managed directly, it is important to understand its dynamics and drivers in order to better predict the amount of soil nitrogen, and consequently the amount of plant production and forage quality, under different management strategies. This information could be used by land owners to optimise their stocking rate and stocking strategies, leading to better management of their forage resource for animal productivity and maintaining land in good condition.

In northern Australia, grazing of native or introduced grasses and legumes without fertiliser application is the main management practice that affects nutrient dynamics and soil quality. It has been suggested that grazing affects soil nutrients through three main pathways in the absence of land degradation: (1) a net primary production pathway; (2) nitrogen pathways; and (3) decomposition pathways (Piñeiro et al. 2010). Because these pathways are not mutually exclusive and are affected by additional ecosystem properties, the effect of grazing on soil supply of nutrients is variable.

Manipulated field trials addressing the effects of grazing on soil supply of plant nutrients in the dry tropics are limited and often short term (Dalal and Carter 2000; Nelson and Roth 2004; for long-term studies, see Holt 1997; Pringle et al. 2011, 2014; Allen et al. 2013). However, it can take many years for some soil nutrients to respond to changes in land use or grazing intensity (Daryanto and Eldridge 2010; Segoli et al. 2012). Therefore, we took the opportunity of using soil samples collected in three different years from the dominant soil complex in an existing long-term grazing trial established in 1997 (O'Reagain et al. 2009) in order to study the effect of grazing intensity (i.e. stocking rates) and interannual rainfall variability on total soil nitrogen, mineral nitrogen and carbon.

In a previous study at the same location using data from a single sampling date, Pringle et al. (2011) showed that soil texture and stocking rate interact to affect soil organic carbon (SOC) stock. They found that the heavier grazing intensity treatment had a higher SOC stock in the dominant Brown Sodosol-Yellow Kandosol complex compared with the moderate grazing intensity treatment. Based on these results, we predicted that the heavy grazing treatment would have higher soil organic matter and lower soil nitrogen compared with the moderate grazing intensity treatment. However, interannual variation in rainfall may have a stronger effect on the soil's supply of plant nutrients, hence masking the long-term effects of grazing management in short-term studies.

\section{Materials and methods}

We used soil samples that were collected at a long-term cattle grazing trial conducted at Wambiana Station $\left(20^{\circ} 34^{\prime} \mathrm{S}\right.$, $\left.146^{\circ} 07^{\prime} \mathrm{E}\right)$, in north Queensland, Australia. The mean annual rainfall of the area is $636 \mathrm{~mm}$, but is highly variable (Table 1), with most of the rainfall (70\%) falling between December and March (O'Reagain et al. 2009). The area has been subjected to cattle grazing at light to moderate stocking rates for at least the past 130 years before the trial's establishment. In 1997, several $\sim 100$-ha paddocks were established to test a range of different grazing strategies (for more detail, see O'Reagain et al. 2009). Two contrasting strategies were selected for the present study: (1) a moderate stocking rate (MSR) treatment at $\sim 8$ ha per animal equivalent ( $450 \mathrm{~kg}$ steer), which is approximately the calculated long-term carrying capacity for the area; and (2) a heavy stocking rate (HSR) treatment at $\sim 4$ ha per animal equivalent (O'Reagain et al. 2009).

There are three major land types within the treatment paddocks, so to minimise this source of variability all soil samples were collected from the dominant Eucalyptus brownii savanna woodland on the Brown Sodosol-Yellow Kandosol complex (Northcote 1960; Cannon 1997; Isbell 2002), which covers approximately $55 \%$ of the site area. Two soil samples were collected to a $30 \mathrm{~cm}$ depth 2 years after the commencement of the trial and general soil properties measured (Table 2). Statistical inference cannot be performed from these limited soil samples, but they suggest that the two treatments were similar at the onset of the manipulation. The area sampled in the MSR and HSR treatments was a subsample of the area sampled by Pringle et al. (2011) and Bray et al. (2014). The area sampled is a relatively homogeneous area that had no apparent differences at the onset of the manipulations, with an arbitrary fence line dividing the grazing treatments. The vegetation consists of an open woodland of $E$. brownii and an understorey of the native shrub Carissa ovata. The grass layer is dominated by native $\mathrm{C}_{4}$ tropical grasses, like Bothriochloa ewartiana and Dichanthium fecundum, but the exotic stoloniferous introduced grass Bothriochloa pertusa has spread widely on the trial area in the past 7-8 years. As a result of the grazing intensity treatment, there were major differences in both pasture total standing dry matter (TSDM) and pasture composition between the two treatments. On average, pasture TSDM was two- to threefold greater in the MSR (range 1324-3144 $\mathrm{kg} \mathrm{ha}^{-1}$ ) than in the HSR treatment (range 419$1090 \mathrm{~kg} \mathrm{ha}^{-1}$ ). At the same time, the relative contribution to yield of the more desirable perennial grasses like $B$. ewartiana

Table 1. Annual rainfall from July to June measured at the study area For monthly rainfall see O'Reagain et al. (2009)

\begin{tabular}{|c|c|c|c|c|c|c|c|c|c|c|c|c|}
\hline Year & 2002 & 2003 & 2004 & 2005 & 2006 & 2007 & 2008 & 2009 & 2010 & 2011 & 2012 & 2013 \\
\hline Annual rainfall $\left(\mathrm{mm}\right.$ year $\left.^{-1}\right)$ & 380 & 407 & 388 & 470 & 469 & 708 & 898 & 1032 & 715 & 1240 & 750 & 606 \\
\hline
\end{tabular}


Table 2. Average of two soil samples that depict general soil properties $(0-30 \mathrm{~cm})$ in the moderate stocking rate (MSR) and heavy stocking rate (HSR) treatments on Brown Sodosol-Yellow Kandosol complex collected in 1999

EC, Electrical conductivity

\begin{tabular}{lccccccccc}
\hline Grazing strategy & $\mathrm{pH}$ & $\begin{array}{c}\text { Coarse sand } \\
(\%)\end{array}$ & $\begin{array}{c}\text { Fine sand } \\
(\%)\end{array}$ & $\begin{array}{c}\text { Silt } \\
(\%)\end{array}$ & $\begin{array}{c}\text { Clay } \\
(\%)\end{array}$ & $\begin{array}{c}\text { Organic C } \\
(\%)\end{array}$ & $\begin{array}{c}\text { EC } \\
\left.(\mathrm{mS} \mathrm{cm})^{-1}\right)\end{array}$ & $\begin{array}{c}\text { Phosphate } \\
\left(\mathrm{mg} \mathrm{kg}^{-1}\right)\end{array}$ & $\begin{array}{c}\text { Potassium } \\
(\%)\end{array}$ \\
\hline MSR & 5.95 & 30 & 40 & 11 & 21 & 0.85 & 0.03 & 3.5 & 0.38 \\
HSR & 6.10 & 30 & 36 & 13 & 24 & 0.88 & 0.05 & 4.0 \\
\hline
\end{tabular}

were approximately twofold greater in the MSR than HSR treatment. In contrast, the frequency and relative contribution to yield of the exotic $B$. pertusa was far higher in the HSR treatment (P. O'Reagain, unpubl. data; O'Reagain and Bushell 2011).

The soil samples were collected in July 2008, March-April 2009 and July 2013. Two adjacent 1-ha square-shaped areas $(100 \times 100 \mathrm{~m})$ were selected on both sides of the arbitrary fence. In each area, 25 cores of $0-10 \mathrm{~cm}$ depth were sampled. However, because of a variety of issues, including missing or insufficient soil for laboratory analyses, the actual sample size was slightly lower (Table 3). Soil samples were dried at $40^{\circ} \mathrm{C}$, large roots removed, soil crushed and passed through a $2-\mathrm{mm}$ sieve. The dry soil was archived in sealed containers for further analysis.

Mineral N (ammonium and nitrate-N) was extracted from the soil by shaking $8 \mathrm{~g}$ soil in $20 \mathrm{~mL}$ potassium chloride $(2 \mathrm{M})$ for $1 \mathrm{~h}$ and filtering through No. 41 filter paper. Nitrate and ammonium were determined in the $\mathrm{KCl}$ extracts by colourimetric methods (Best 1976; Keeney and Nelson 1982; Willis et al. 1993). Soil organic matter content was determined by the loss-on-ignition method (Segoli et al. 2012). Spain et al. (1982) demonstrated that loss-on-ignition provides a robust indicator of soil organic matter and organic carbon content in soils with low contents of carbonate and hydrous oxides, on similar soils to those examined herein.

The 2008 soils were subsampled to obtain total nitrogen and $\delta 13 \mathrm{C}$. Analysis was undertaken using an Isoprime isotope ratio mass spectrometer (IRMS) coupled to a Eurovector elemental analyser (Isoprime-EuroEA 3000, Isoprime Ltd, Stockport, UK) with $\mathrm{HCl}$ pre-treatment (concentration 10\%) to remove carbonates (see Pringle et al. (2011), for further detail). Approximately $20 \mathrm{mg}$ fine-ground soil was weighed into an $8 \times 5 \mathrm{~mm}$ tin $(\mathrm{Sn})$ capsule and analysed against a known set of standards (ANU Sucrose for ${ }^{13} \mathrm{C}$ ).

The effects of grazing intensity were subjected to a $t$-test, and, when variances were significantly different between groups, a $t$-test with separate variance was performed (Zar 1999). The relationship between soil organic matter and $\delta^{13} \mathrm{C}$ was analysed using Pearson correlation (Zar 1999). All statistical analyses were conducted using STATISTICA 12.0 software (StatSoft Inc., Tulsa, OK, USA).

\section{Results}

The soil organic matter content was higher in the heavy grazing treatment in all years (Fig. 1a), although this was only significant in 2008 and 2009 (2008: $t$-test $t_{45}=-2.79, P<0.01 ; 2009$ : $t$-test $t_{46}=-2.74, P<0.01 ; 2013$ : $t$-test $\left.t_{43}=-1.62, P=0.11\right)$. Grazing treatment had no significant effect on the $\delta^{13} \mathrm{C}$ signature in 2008 (Fig. 2; $t$-test $t_{45}=0.44, P=0.66$ ). However, $\delta^{13} \mathrm{C}$ was
Table 3. Number of soil samples analysed at $0-10 \mathrm{~cm}$ depth for the different soil measurements in the different years and in different treatments on Brown Sodosol-Yellow Kandosol complex

SOM, Soil organic matter; MSR, moderate stocking rate; HSR heavy stocking rate

\begin{tabular}{lcccc}
\hline Year & Grazing pressure & $\mathrm{SOM}$ & $\mathrm{NO}_{3}$ & $\mathrm{NH}_{4}$ \\
\hline 2008 & MSR & 22 & 25 & 25 \\
2008 & HSR & 25 & 25 & 25 \\
2009 & MSR & 25 & 25 & 25 \\
2009 & HSR & 23 & 25 & 25 \\
2013 & MSR & 25 & 25 & 25 \\
2013 & HSR & 20 & 20 & 20 \\
\hline
\end{tabular}

negatively correlated with organic matter in $2008(r=-0.50$, $P<0.01)$.

Nitrate content varied among the years (Fig. 1b) and was significantly higher in the moderate grazing treatment in 2008 and 2009 (2008: $t$-test $t_{48}=-2.04, P<0.05 ; 2009: t$-test $t_{48}=-2.35, P=0.02 ; 2013:$-test $\left.t_{43}=-0.90, P=0.37\right)$.

Ammonium content also varied among years (Fig. 1c). Ammonium content was higher in the heavy grazing treatment in 2008 and 2009, but was lower in the heavy grazing treatment in 2013 (2008: $t$-test with separate variance $t_{31,25}=-2.73, P=0.01$; 2009: $t$-test with separate variance $t_{35,59}=-3.28, P<0.01 ; 2013$ : $t$-test with separate variance $t_{30,41}=2.59, P=0.01$ ).

Grazing treatment had no significant effect on the total nitrogen content in 2008 (Fig. 3; $t$-test $t_{45}=1.15, P=0.26$ ).

\section{Discussion}

Commercial grazing is the dominant land use in the tropical semi-arid ecosystems of northern Australia (Cook et al. 2010). It is expected that grazing management will affect nutrient cycling in soils. We used a long-term grazing trial to test the effects of cattle stocking rates on interannual differences in soil organic matter, soil total nitrogen and soil mineral nitrogen. The results suggest that on Brown Sodosol-Yellow Kandosol complex, the HSR treatment had higher soil organic matter compared with the MSR treatment, consistent with Pringle et al. (2011), and with little interannual variability (Fig. 1a). The relatively small increase in soil organic matter under the HSR suggests a negligible ecological effect at the local scale. However, extrapolation of this small change over the large area occupied by commercial cattle grazing in northern Australia could affect national- or even global-scale processes (Ash et al. 1995). In contrast with soil organic matter, interannual variability was greater for soil mineral nitrogen, with no consistent effect of grazing treatment (Fig. 1b, $c$ ). This suggests that soil mineral nitrogen is relatively resistant to grazing, even at different rainfall intensities. 

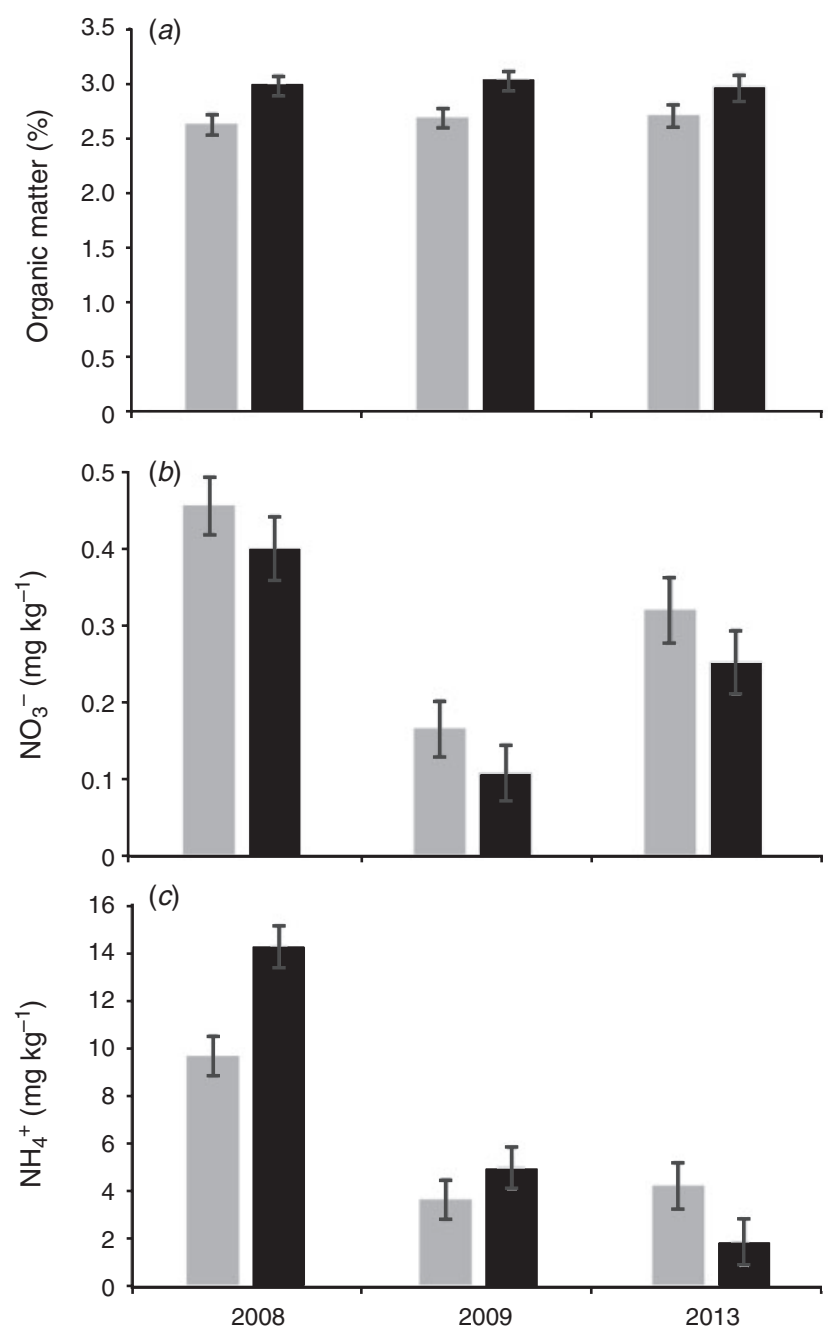

Fig. 1. (a) Soil organic matter, (b) nitrate, and (c) ammonium contents at $0-10 \mathrm{~cm}$ soil depth under moderate (grey) and heavy (black) grazing intensity rates on Brown Sodosol-Yellow Kandosol complex in 2008, 2009 and 2013. Data are the mean \pm s.e.

Pringle et al. (2011) explained the higher SOC in the HSR on this soil complex by a lower $\delta^{13} \mathrm{C}$ signature, suggesting a higher contribution to $\mathrm{SOC}$ from $\mathrm{C}_{3}$ shrubs and trees relative to the $\mathrm{C}_{4}$ perennial grasses (Krull and Bray 2005). After a fire in the treatments in 1999, the cover of the sprawling shrub C. ovata increased faster in the HSR than MSR treatment (Bray et al. 2014), but there was no significant difference in the total woody vegetation cover between the treatments (Bray et al. 2014; P. O'Reagain, unpubl. data). Preliminary soil analyses suggest that soil under $C$. ovata shrubs contains more carbon than surrounding soil (S. Bray, unpubl. data). The present data support the conclusions of Pringle et al. (2011) because we found a negative correlation between $\delta^{13} \mathrm{C}$ and soil organic matter, although no significant difference in $\delta^{13} \mathrm{C}$ was found between the grazing treatments. It is possible that our finding reflects the effects of depth and spatial scale on the strength of the correlation, or that the present experiment was too short to detect the effects of grazing on $\delta^{13} \mathrm{C}$ in total organic carbon

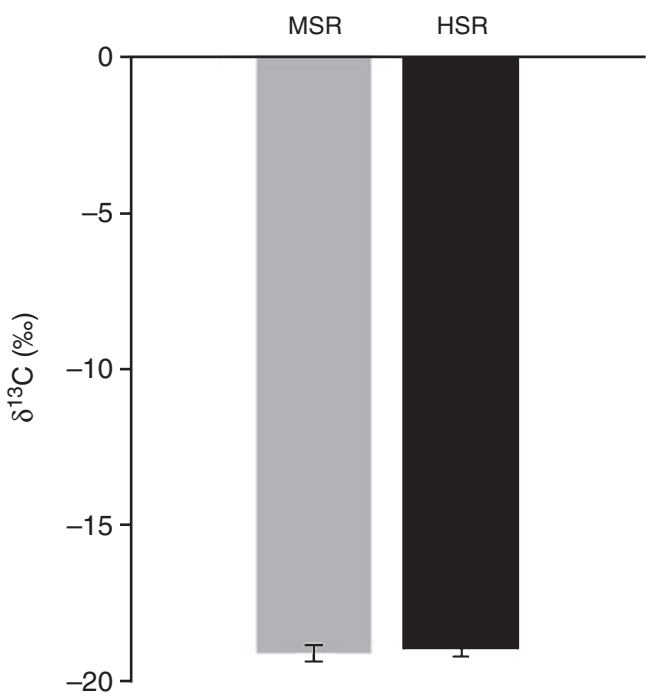

Fig. 2. $\delta^{13} \mathrm{C}$ values at $0-10 \mathrm{~cm}$ soil depth under moderate and heavy stocking rates (MSR and HSR, respectively) on Brown Sodosol-Yellow Kandosol complex in 2008. Data are the mean \pm s.e.

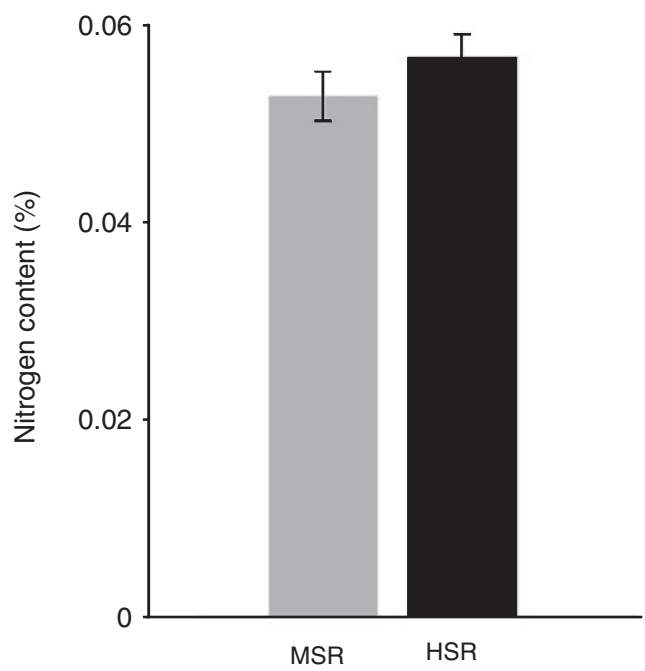

Fig. 3. Total soil nitrogen content at $0-10 \mathrm{~cm}$ soil depth under moderate and heavy stocking rates (MSR and HSR, respectively) on Brown Sodosol-Yellow Kandosol complex in 2008. Data are the mean \pm s.e.

(Pringle et al. 2011). Perhaps examining the $\delta^{13} \mathrm{C}$ by aggregate fractions could enhance the sensitivity and enable detection of the effects of grazing (Krull and Bray 2005).

The results found in the Brown Sodosol-Yellow Kandosol complex at the Wambiana site are not consistent with other soil organic matter studies on different soils in northern Australia (Ash et al. 1995; Holt 1997; Badgery et al. 2013; Cowie et al. 2013; Pringle et al. 2014). For example, Pringle et al. (2011) found that SOC stocks (soil organic $\mathrm{C}$ concentration $\times$ bulk density $\times$ soil depth) at $0-10 \mathrm{~cm}$ depth were lower under high than low stocking rates on different soil types, namely a Grey Vertosol and a Red Kandosol, at the same trial site. In a recent survey of 98 sites, Allen et al. (2013) found a small but significant negative relationship between stocking rates and SOC. However, 
they concluded that the main drivers for SOC were climate and soil type. It was suggested that stocking rates affect SOC through changes in TSDM, grass species composition and root mass (O'Reagain and Bushell 2011; Badgery et al. 2013). In another long-term 26-year study of sheep grazing intensity on a Grey Vertosol, Pringle et al. (2014) found no significant difference in SOC stocks between six pasture utilisation rates ranging from $0 \%$ (exclosure) to $80 \%$ utilisation. However, there was a significant loss of total nitrogen from the topsoil under intensive pasture utilisation. Furthermore, a slight visual trend of declining SOC was found at higher utilisation rates.

The variability and inconsistency of results within and between studies across northern Australia indicate that caution is required when making claims on the benefits of improved grazing management on soil $\mathrm{C}$ stocks and nutrients in northern Australia. Although heavy grazing increased SOC on one soil in the present study, most other studies have found that heavy grazing can have severe negative effects, such as increased soil erosion (Eldridge 1998; O'Reagain et al. 2005), woody encroachment (Daryanto et al. 2013), changed species composition (Orr et al. 2010; Ash et al. 2011; Orr and Phelps 2013), reduced ground cover and soil surface condition (Ash et al. 2011). In addition, it has been shown that, in the longer term, heavy grazing reduces animal production and profitability (O'Reagain et al. 2009; O'Reagain and Bushell 2011).

In addition, combining these results with other results from different soils can increase the predictive value of models, which are important for underpinning the calculation of Australia's national greenhouse accounts. National predictions of the effects of land use change need to include soil type in their assessments to reduce uncertainties and errors (Segoli et al. 2013). Furthermore, it is important for the landowner to know which soils are likely to sequester carbon with changes in land use. More research is needed on different soil types and variability within paddocks in order to build a practical managerial plan and make more accurate predictions on the long-term consequences of different management systems on soil carbon, carbon sequestration and greenhouse gas accounting. Special attention should be given to the effect of woody vegetation on soil carbon.

The interannual variability in soil nitrate content was greater than the effect of grazing intensity, probably because of the natural variability of nitrate content at seasonal and annual time scales (Liebig et al. 2014). For example, the lower nitrate content in 2009 than the other two years may reflect sampling season, because 2009 sampling was performed during the growing season when nitrate uptake by plants would be high as opposed to the other years, when the sampling was performed in the dry season (Chen et al. 2001). The higher amount of nitrate and ammonium in 2008 could be explained by the below-average rainfall observed during previous years (Table 1) that caused an accumulation of mineral nitrogen (Liebig et al. 2014). An absence of reliable measured data before the commencement of the experimental grazing trial restricts our capacity to attribute observed changes to long-term management. However, the fact that no biologically meaningful differences in mineral nitrogen were apparent after 20 years suggests that climate, rather than grazing intensity, is the main driver of mineral nitrogen dynamics. This is probable because atmospheric deposition is the dominant source of reactive nitrogen (Bobbink et al. 2010) and most of the plant nutrients consumed by livestock return to the soil (Chen et al. 2001). This also emphasises the importance of studying the effect of rainfall on soil nitrogen and the carry-over effect from previous years (Liebig et al. 2014). Better understanding of the dynamics of soil nitrogen and its drivers should improve our ability to predict levels of available soil nitrogen. This will likely lead to better management of stocking rates and grazing strategies that increase profitability and reduce land degradation.

\section{Acknowledgements}

The authors thank Paul Nelson, Sue Berthelsen and Xavier Mayot for laboratory assistance.

\section{References}

Allen DE, Pringle MJ, Bray S, Hall TJ, O'Reagain PJ, Phelps D, Cobon DH, Bloesch PM, Dalal RC (2013) What determines soil organic carbon stocks in the grazing lands of north-eastern Australia? Soil Research 51, 695-706. doi:10.1071/SR13041

Ash A, McIvor J (1995) Land condition in the tropical tall grass pasture lands. 2. Effects on herbage quality and nutrient uptake. The Rangeland Journal 17, 86-98. doi:10.1071/RJ9950086

Ash AJ, Howden SM, McIvor JG (1995) Improved rangeland management and its implications for carbon sequestration. In 'Rangelands in a sustainable biosphere. Vol. 1. Proceedings of the Fifth International Rangelands Congress'. (Ed. NE West) pp. 19-20. (Society for Range Management: Salt Lake City, UT)

Ash AJ, Corfield JP, McIvor JG, Ksiksi TS (2011) Grazing management in tropical savannas: utilization and rest strategies to manipulate rangeland condition. Rangeland Ecology and Management 64, 223-239. doi:10.2111/REM-D-09-00111.1

Badgery W, King H, Simmons A, Murphy B, Rawson A, Warden E (2013) The effects of management and vegetation on soil carbon stocks in temperate Australian grazing systems. In 'Proceedings of the 22nd International Grasslands Congress. Revitalising grasslands to sustain our communities'. (Ed. DL Michalk) pp. 1223-1226. (New South Wales Dept of Primary Industries: Orange, NSW)

Best EK (1976) An automated method for determining nitrate-nitrogen in soil extracts. Queensland Journal of Agricultural and Animal Sciences 33, 161-166.

Bobbink R, Hicks K, Galloway J, Spranger T, Alkemade R, Ashmore M, Bustamante M, Cinderby S, Davidson E, Dentener F, Emmett B, Erisman JW, Fenn M, Gilliam F, Nordin A, Pardo L, De Vries W (2010) Global assessment of nitrogen deposition effects on terrestrial plant diversity: a synthesis. Ecological Applications 20, 30-59. doi:10.1890/08-1140.1

Bray S, Doran-Browne N, O'Reagain PJ (2014) Northern Australian pasture and beef systems. 1. Net carbon position. Animal Production Science 54, 1988-1994. doi:10.1071/AN14604

Cannon M (1997) Preliminary soil survey of the proposed grazing trial area at Wambiana Station, Charters Towers north Queensland. Unpublished report.

Carberry PS, Muchow RC, McCown RL (1993) A simulation-model of kenaf for assisting fiber industry planning in northern Australia. 4. Analysis of climatic risk. Australian Journal of Agricultural Research 44, 713-730. doi:10.1071/AR9930713

Chen W, McCaughey WP, Grant CA, Bailey LD (2001) Pasture type and fertilization effects on soil chemical properties and nutrient redistribution. Canadian Journal of Soil Science 81, 395-404. doi:10.4141/S99-103

Cook GD, Williams RJ, Stokes CJ, Hutley LB, Ash AJ, Richards AE (2010) Managing sources and sinks of greenhouse gases in Australia's rangelands and tropical savannas. Rangeland Ecology and Management 63, 137-146. doi:10.2111/08-101.1 
Cowie AL, Lonergan VE, Rabbi SMF, Fornasier F, Macdonald C, Harden S, Kawasaki A, Singh BK (2013) Impact of carbon farming practices on soil carbon in northern New South Wales. Soil Research 51, 707-718. doi:10.1071/SR13043

Dalal RC, Carter JO (2000) Soil organic matter dynamics and carbon sequestration in Australian tropical soils. In 'Global climate change and tropical ecosystems'. (Eds R Lal, JM Kimble) pp. 283-314. (CRC Press: Boca Raton, FL)

Daryanto S, Eldridge DJ (2010) Plant and soil surface responses to a combination of shrub removal and grazing in a shrub-encroached woodland. Journal of Environmental Management 91, 2639-2648. doi:10.1016/j.jenvman.2010.07.038

Daryanto S, Eldridge DJ, Throop HL (2013) Managing semi-arid woodlands for carbon storage: grazing and shrub effects on above- and belowground carbon. Agriculture, Ecosystems \& Environment 169, 1-11. doi:10.1016/ j.agee.2013.02.001

Eady S, Grundy M, Battaglia M, Keating B (Eds) (2009) 'An analysis of greenhouse gas mitigation and carbon biosequestration opportunities from rural land use.' (CSIRO: St Lucia, Qld)

Eldridge DJ (1998) Trampling of microphytic crusts on calcareous soils, and its impact on erosion under rain-impacted flow. Catena 33, 221-239. doi:10.1016/S0341-8162(98)00075-7

Garnaut R (2008) 'The Garnaut climate change review.' (Cambridge University Press: Melbourne)

Gifford RM (2010) Carbon sequestration in Australian grasslands: policy and technical issues. In 'Grassland carbon sequestration: management, policy and economics. Proceedings of the workshop on the role of grassland carbon sequestration in the mitigation of climate change'. (Eds RC Michael Abberton, Caterina Batello) pp. 33-56. (FAO: Rome)

Holt JA (1997) Grazing pressure and soil carbon, microbial biomass and enzyme activities in semi-arid northeastern Australia. Applied Soil Ecology 5, 143-149. doi:10.1016/S0929-1393(96)00145-X

Isbell RF (2002) 'The Australian soil classification.' (CSIRO Publishing: Melbourne)

Keeney DR, Nelson DW (1982) Nitrogen - inorganic forms. In 'Methods of soil analysis. Part 2. Chemical and microbiological properties'. (Ed. AL Page) pp. 643-698. (American Society of Agronomy, Soil Science Society of America: Madison, WI)

Krull EG, Bray SS (2005) Assessment of vegetation change and landscape variability by using stable carbon isotopes of soil organic matter. Australian Journal of Botany 53, 651-661. doi:10.1071/BT04124

Liebig MA, Kronberg SL, Hendrickson JR, Gross JR (2014) Grazing management, season, and drought contributions to near-surface soil property dynamics in semiarid rangeland. Rangeland Ecology and Management 67, 266-274. doi:10.2111/REM-D-13-00145.1

McLean I, Holmes P, Counsell D (2014) 'The northern beef report 2013. Northern beef situation analysis.' (Meat \& Livestock Australia Ltd: Sydney)

McSherry ME, Ritchie ME (2013) Effects of grazing on grassland soil carbon: a global review. Global Change Biology 19, 1347-1357. doi:10.1111/gcb.12144

Mott JJ, Williams J, Andrew MA, Gillison AN (1985) Australian savanna ecosystems. In 'Ecology and management of the world's savannas'. (Eds JC Tothill, JJ Mott) pp. 56-82. (Australian Academy of Science: Canberra, ACT)

Nelson P, Roth C (2004) Water and nutrient cycling processes. In 'Healthy rangelands: principles for sustainable systems: focus on Australia's
Burdekin rangelands'. (Eds M McCullough, B Musso) pp. 23-67. (Tropical Savannas CRC: Darwin, NT)

Northcote KH (1960) ‘Atlas of Australian soils.' (CSIRO, Division of Soils: Melbourne)

O'Reagain PJ, Bushell JJ (2011) 'The Wambiana grazing trial: key learnings for sustainable and profitable management in a variable environment.' (Department of Employment, Economic Development and Innovation: Brisbane)

O'Reagain PJ, Brodie J, Fraser G, Bushell JJ, Holloway CH, Faithful JW, Haynes D (2005) Nutrient loss and water quality under extensive grazing in the upper Burdekin river catchment, north Queensland. Marine Pollution Bulletin 51, 37-50. doi:10.1016/j.marpolbul.2004.10.023

O'Reagain PJ, Bushell J, Holloway C, Reid A (2009) Managing for rainfall variability: effect of grazing strategy on cattle production in a dry tropical savanna. Animal Production Science 49, 85-99. doi:10.1071/EA07187

Orr DM, Phelps DG (2013) Impacts of level of utilisation by grazing on an Astrebla (Mitchell grass) grassland in north-western Queensland between 1984 and 2010. 2. Plant species richness and abundance. The Rangeland Journal 35, 17-28. doi:10.1071/RJ11069

Orr DM, Yee MC, Rutherford MT, Paton CJ (2010) Impacts of grazing management options on pasture and animal productivity in a Heteropogon contortus (black speargrass) pasture in central Queensland. 2. Population dynamics of Heteropogon contortus and Stylosanthes scabra cv. Seca. Crop \& Pasture Science 61, 255-267. doi:10.1071/CP09194

Piñeiro G, Paruelo JM, Oesterheld M, Jobbágy EG (2010) Pathways of grazing effects on soil organic carbon and nitrogen. Rangeland Ecology and Management 63, 109-119. doi:10.2111/08-255.1

Pringle MJ, Allen DE, Dalal RC, Payne JE, Mayer DG, O'Reagain PJ, Marchant BP (2011) Soil carbon stock in the tropical rangelands of Australia: effects of soil type and grazing pressure, and determination of sampling requirement. Geoderma 167-168, 261-273. doi:10.1016/j. geoderma.2011.09.001

Pringle MJ, Allen DE, Phelps DG, Bray SG, Orton TG, Dalal RC (2014) The effect of pasture utilization rate on stocks of soil organic carbon and total nitrogen in a semi-arid tropical grassland. Agriculture, Ecosystems \& Environment 195, 83-90. doi:10.1016/j.agee.2014.05.013

Segoli M, Ungar ED, Shachak M (2012) Fine-scale spatial heterogeneity of resource modulation in semi-arid 'islands of fertility'. Arid Land Research and Management 26, 344-354. doi:10.1080/15324982.2012. 694397

Segoli M, De Gryze S, Dou F, Lee J, Post WM, Denef K, Six J (2013) AggModel: a soil organic matter model with measurable pools for use in incubation studies. Ecological Modelling 263, 1-9. doi:10.1016/ j.ecolmodel.2013.04.010

Spain AV, Probert ME, Isbell RF, John RD (1982) Loss-on-ignition and the carbon contents of Australian soils. Australian Journal of Soil Research 20, 147-152. doi:10.1071/SR9820147

Wedin DA (1995) Species, nitrogen, and grassland dynamics: the constraints of stuff. In 'Linking species \& ecosystems'. (Eds CG Jones, JH Lawton) pp. 253-262. (Chapman \& Hall: New York)

Willis RB, Schwab GJ, Gentry CE (1993) Elimination of interferences in the colorimetric analysis of ammonium in water and soil extracts. Communications in Soil Science and Plant Analysis 24, 1009-1019. doi: $10.1080 / 00103629309368857$

Zar JH (1999) 'Biostatistical analysis.' 4th edn. (Prentice Hall: Upper Saddle River, NJ) 